\title{
Up-Regulation of Heme Oxygenase by Nitric Oxide and Effect of Carbon Monoxide on Soybean Plants Subjected to Salinity
}

\author{
Guillermo Noriega, Carla Zilli, Diego Santa Cruz, Ethel Caggiano, \\ Manuel López Lecube, María Tomaro and Karina Balestrasse \\ University of Buenos Aires, Consejo Nacional de Investigaciones Científicas y Técnicas \\ Argentina
}

\section{Introduction}

Reactive oxygen species (ROS) are generated in small amounts in the normal metabolism of the cells and in increased amounts under many conditions of altered cell physiology; they are responsible for many kinds of cell injuries (Sies 1993) and have been shown to induce a significant reprogramming of gene expression (Colburn 1992).

Salt stress is one of the most important abiotic stresses that adversely affects soybean growth and causes significant crop loss worldwide. Salinity has always been considered a serious constraint on agricultural productivity (Hay \& Porter 2006) and affects plant's physiology. Salt stress is a complex phenomenon that involves morphological and developmental changes. Two major components have been identified in this insult, osmotic stress and ion toxicity (Darwish et al. 2009). Higher plants have multiple protective mechanisms against salt stress including ion homeostasis, osmolyte biosynthesis, ROS scavenging, water transport, and transducers of long-distance response coordination. It is generally accepted that many stresses, including salinity, induce an overproduction of ROS, such as $\mathrm{H}_{2} \mathrm{O}_{2}, \mathrm{O}_{2} \bullet-$, and $\mathrm{HO}$, and these species are thought to be responsible for the oxidative damage associated with plant stress (Zilli et al. 2009). To counteract the toxicity of ROS, defense systems that scavenge cellular ROS have been developed in plants to cope with oxidative stress via the non-enzymatic and enzymatic systems (Demiral \& Turkan 2005; Mandhania et al. 2006)

Nitric oxide (NO) acts as a signaling molecule and mediates multiple physiological processes in plants (Leitner et al. 2009). In addition, it has been implicated in responses to biotic and abiotic stresses, such as disease resistance, salinity, drought, heat stress, among others (Beligni \& Lamattina 1999; Romero-Puerta et al. 2004; Corpas et al. 2009). There are several sources of NO in plants, but mainly it can be enzymatically produced by nitrate reductase and nitric oxide synthase-like enzymes (Wilson et al. 2008 and Corpas et al. 2009). NO is a reactive nitrogen species and, depending on its concentration, it produces either protective or toxic effects. A low dose of $\mathrm{NO}$ modulates superoxide anion formation and inhibits lipid peroxidation, resulting in an antioxidant function during stress (Boveris et al. 2000 and Santa Cruz et al. 2010). Moreover, microarray studies have shown that NO induces a large number of genes at transcriptional level, among them those of antioxidant enzymes (Parani et al. 2004). It has also been reported that Nitric oxide gives rise to signaling pathways mediating 
responses of specific genes to ultraviolet-B (UV-B) radiation, such as chalcone synthase and phenylalanine ammonia lyase (Mackerness et al. 2001). However, information about the role that NO plays in regulation of antioxidant enzymes to counteract salt-induced oxidative stress is rather limited.

Nitric oxide is believed to act as a signal molecule mediating responses to both biotic and abiotic stresses in plants (reviewed in Xuan et al. 2010 and Nürnberger \& Scheel 2001) and its presence has been shown to induce seed germination (Liu et al. 2010), to affect growth and development of plant tissue (Beligni \& Lamatina 2001, to increase iron homeostasis (Martin et al. 2009), to regulate plant maturation and senescence (Yaacov et al. 1998 and Jasid et al. 2009) to mediate abscisic acid-induced stomatal closing (Garcia-Mata \& Lamattina, 2007). Recently, a few studies suggested that $\mathrm{NO}$ can play a role in protecting plants from oxidative stresses (Shantel et al. 2008) and NO-donor treatment protected plants from damage by increasing the activity of antioxidative enzymes.

Heme oxygenase catalyzes the oxidative degradation of heme and has well-known antioxidant properties in mammals by mean of its products biliverdin IXa and carbon monoxide (CO) (Kikuchi et al. 2005). One of the three known mammalian isoforms, heme oxygenase-1 (HO-1), is induced in animal tissues by many factors including its own substrate heme, heavy metals, UV-A radiation among others (Tomaro \& Batlle 2002). While earlier studies pointed to plant $\mathrm{HO}$ as a source of phytochrome chromophore (Terry et al. 2002), more recent works showed that $\mathrm{HO}$ synthesis increases in soybean plants subjected to oxidative stress conferring resistance to a subsequent insult (Noriega et al. 2004; Balestrasse et al. 2005). Moreover, we have recently demonstrated that ROS are involved in HO-1 upregulation in soybean leaves subjected to UV-B radiation (Yannarelli et al. 2006 and Santa Cruz et al. 2010). We hypothesized that NO may also participate in this process, as it regulates the oxidative status and mediates other UV-B responses.

The aim of the present study was to investigate whether $\mathrm{NO}$ or $\mathrm{CO}$ could protect soybean against salt-induced oxidative stress through the modulation of $\mathrm{HO}$ activity. Soybean plants were subjected to salt stress after pre-treatments with different concentrations of sodium nitroprussiate (SNP), a well-characterized NO-donor or CO. Overall, our results indicate that in soybean plants $\mathrm{NO}$ is involved in the signaling pathway leading to HO-1 upregulation under salinity, and that a balance between NO and ROS is important to trigger the antioxidant response against oxidative stress. On the other hand pretreatment with $\mathrm{CO}$ did not provoke any change.

\section{Materials and methods}

\subsection{Plant material and treatments}

Surface sterilized soybean seeds (Glycine max. L.) (A6445RG) were germinated for 10 days in plastic pots containing vermiculite in controlled environmental chambers, with a photoperiod of $16 \mathrm{~h}$, photon flux density of $175 \mu \mathrm{mol} \mathrm{m} \mathrm{m}^{-2} \mathrm{~s}^{-1}$, and a day/night regime of $25 / 20^{\circ} \mathrm{C}$. Afterwards, they were pretreated hydroponically with different sodium nitroprusiate concentrations $(250-750 \mu \mathrm{M})$ for $72 \mathrm{~h}$ and then with $\mathrm{NaCl}(200 \mathrm{mM})$ for $48 \mathrm{~h}$.

Carbon monoxide was generated from $\mathrm{H}_{2} \mathrm{SO}_{4}$ and formic acid (HCOOH). Stock solution was prepared by bubbling $\mathrm{CO}$ in a Hoagland solution for $40 \mathrm{~min}$ and was immediately diluted (50\%) to perform analysis.

Plants were then harvested. When the effect of Zn-protoporphyrin IX (ZnPPIX) was investigated, roots were pretreated with $22 \mu \mathrm{M}$ ZnPPIX during $4 \mathrm{~h}$ before addition of $\mathrm{NaCl}$. 
Controls were incubated in buffer. For fresh weight determination, plants were filtered, washed three times with distilled water, kept on filter paper for a few minutes to remove of excess liquid and weighed. Three different experiments were performed, with three replicated measurements for each parameter assayed

\subsection{Thiobarbituric acid reactive substances (TBARS) determination}

Lipid peroxidation was measured as the amount of TBARS determined by the thiobarbituric acid (TBA) reaction as described by Heath and Packer (1968). Fresh control and treated roots $(0.3 \mathrm{~g})$ were homogenized in $3 \mathrm{ml}$ of $20 \%(\mathrm{w} / \mathrm{v})$ trichloroacetic acid (TCA). The homogenate was centrifuged at 3,500 $\times \mathrm{g}$ for $20 \mathrm{~min}$. To $1 \mathrm{ml}$ of the aliquot of the supernatant, $1 \mathrm{ml}$ of $20 \%$ TCA containing $0.5 \%(\mathrm{w} / \mathrm{v})$ TBA and $100 \mathrm{ml} 4 \%$ butylated hydroxytoluene (BHT) in ethanol were added. The mixture was heated at $95^{\circ} \mathrm{C}$ for $30 \mathrm{~min}$ and then quickly cooled on ice. The contents were centrifuged at 10,000 $\mathrm{xg}$ for $15 \mathrm{~min}$ and the absorbance was measured at 532 $\mathrm{nm}$. Value for non-specific absorption at $600 \mathrm{~nm}$ was substracted. The concentration of TBARS was calculated using an extinction coefficient of $155 \mathrm{mM}^{-1} \mathrm{~cm}^{-1}$

\subsection{Heme oxygenase preparation and assay}

Roots $(0.3 \mathrm{~g})$ were homogenized in a Potter-Elvehejm homogenizer using 4 vol. of ice-cold $0.25 \mathrm{M}$ sucrose solution containing $1 \mathrm{mM}$ phenylmethyl sulfonyl fluoride, $0.2 \mathrm{mM}$ EDTA and $50 \mathrm{mM}$ potassium phosphate buffer $(\mathrm{pH} 7.4)$. Homogenates were centrifuged at 20,000 x $\mathrm{g}$ for 20min and supernatant fractions were used for activity determination. Heme oxygenase activity was determined as previously described with minor modifications (Muramoto et al. 2002). The standard incubation mixture in a final volume of $500 \mathrm{ml}$ contained $10 \mathrm{mmol}$ potassium phosphate buffer ( $\mathrm{pH} 7.4), 60 \mathrm{nmol} \mathrm{NADPH}, 250 \mathrm{ml} \mathrm{HO}(0.5 \mathrm{mg}$ protein), and 200 $\mathrm{nmol}$ hemin. Incubations were carried out at $378^{\circ} \mathrm{C}$ during $60 \mathrm{~min}$. Activity was determined by measuring biliverdin formation, which was calculated using the absorbance change at $650 \mathrm{~nm}$ employing an 1 value of $6.25 \mathrm{mM}^{-1} \mathrm{~cm}^{-1}($ vis $\max 650 \mathrm{~nm})$

\subsection{Glutathione determination}

Non-protein thiols were extracted by homogenizing $0.3 \mathrm{~g}$ of roots in $3.0 \mathrm{ml}$ of $0.1 \mathrm{~N} \mathrm{HCl}$ (pH 2.0), and $1 \mathrm{~g}$ PVP. After centrifugation at $10,000 \times \mathrm{g}$ for $30 \mathrm{~min}$ at $4^{\circ} \mathrm{C}$, the supernatants were used for analysis. Total glutathione (GSH plus GSSG) was determined in the homogenates spectrophotometrically at $412 \mathrm{~nm}$, after precipitation with $0.1 \mathrm{~N} \mathrm{HCl}$, using yeastglutathione reductase, 5,5' dithio-bis-(2-nitrobenzoic acid) (DTNB) and NADPH. GSSG was determined by the same method in the presence of 2-vinylpyridine and GSH content was calculated from the difference between total glutathione and GSSG (Anderson, 1985).

\subsection{Classical antioxidant enzymes}

Extracts for determination of catalase (CAT), ascorbate peroxidase (APX) and glutathione reductase (GR) activities were prepared from $0.3 \mathrm{~g}$ of roots homogenized under ice-cold conditions in $3 \mathrm{ml}$ of extraction buffer, containing $50 \mathrm{mM}$ phosphate buffer ( $\mathrm{pH} 7.4), 1 \mathrm{mM}$ EDTA, $1 \mathrm{~g}$ PVP, and $0.5 \%(\mathrm{v} / \mathrm{v})$ Triton $\mathrm{X}-100$ at $4{ }^{\circ} \mathrm{C}$. The homogenates were centrifuged at $10,000 \times \mathrm{g}$ for $20 \mathrm{~min}$ and the supernatant fraction was used for the assays.

CAT activity was determined in the homogenates by measuring the decrease in absorption at $240 \mathrm{~nm}$ in a reaction medium containing $50 \mathrm{mM}$ potassium phosphate buffer ( $\mathrm{pH} 7.2)$ and $2 \mathrm{mM} \mathrm{H}_{2} \mathrm{O}_{2}$. The pseudo-first order reaction constant $\left(\mathrm{k}^{\prime}=\mathrm{k}[\mathrm{CAT}]\right)$ of the decrease in $\mathrm{H}_{2} \mathrm{O}_{2}$ 
absorption was determined and the catalase content in pmol mg-1 protein was calculated using $\mathrm{k}=4.7 \times 10^{7} \mathrm{M}^{-1} \mathrm{~s}^{-1}$.

APX activity was measured immediately in fresh extracts and was assayed as described by Nakano and Asada (1981), using a reaction mixture $(1 \mathrm{ml})$ containing $50 \mathrm{mM}$ K-phosphate buffer ( $\mathrm{pH} 7.0$ ), $0.1 \mathrm{mM} \mathrm{H} \mathrm{O}_{2}, 0.5 \mathrm{mM} \mathrm{Na-Ascorbate}$ and $0.1 \mathrm{mM}$ EDTA. The hydrogen peroxide-dependent oxidation of Ascorbate was followed by a decrease in the absorbance at $290 \mathrm{~nm}\left(\varepsilon: 2.8 \mathrm{mM}^{-1} \mathrm{~cm}^{-1}\right)$. One unit of APX forms $1 \mu \mathrm{mol}$ of ascorbate oxidized per minute under the assay conditions.

GR activity was measured by following the decrease in absorbance at $340 \mathrm{~nm}$ due to NADPH oxidation. The reaction mixture contained tissue extract, $1 \mathrm{mM}$ EDTA, $0.5 \mathrm{mM}$ GSSG, $0.15 \mathrm{mM}$ NADPH and $50 \mathrm{mM}$ Tris- $\mathrm{HCl}$ buffer (pH 7.5) and $3 \mathrm{mM} \mathrm{MgCl}$ (Schaedle and Bassham 1977).

\subsection{Histochemical analysis}

In order to analyze $\mathrm{H}_{2} \mathrm{O}_{2}$ generation roots were excised and immersed in a $1 \%$ solution of 3,3'-Diaminobenzidine (DAB) in Tris- $\mathrm{HCl}$ buffer ( $\mathrm{pH}$ 6.5), vacuum-infiltrated for $5 \mathrm{~min}$ and then incubated at room temperature for $16 \mathrm{~h}$ in the absence of light. Roots were illuminated until appearance of brown colors characteristic of the reaction of DAB with $\mathrm{H}_{2} \mathrm{O}_{2}$.

In the same way to show $\mathrm{O}_{2}$ - production roots were excised and immersed in a $0.1 \%$ solution of NBT in K-phosphate buffer ( $\mathrm{pH}$ 6.4), containing $10 \mathrm{mM}$ Na-azide, and were vacuum-infiltrated for 5 min and illuminated until appearance of dark spots, characteristic of blue formazan precipitate.

\subsection{Isolation of RNA and RT-PCR analysis}

Total RNA was extracted from soybean roots by using the Trizol reagent (Gibco BRL). Four micrograms of total RNA were treated with RNase-free DNase I (Promega, CA, USA) and then $1.0 \mu \mathrm{g}$ was reversed transcribed into cDNA using random hexamers and M-MLV Superscript II RT (Invitrogen, CA, USA). PCR reactions were carried out using Glycine max HO-1 and 18S specific primers, as previously described (Yannarelli and others, 2006). The PCR profile was set at $94^{\circ} \mathrm{C}$ for $1 \mathrm{~min}$ and then 29 cycles at $94^{\circ} \mathrm{C}$ for $0.5 \mathrm{~min}, 54^{\circ} \mathrm{C}$ for $1 \mathrm{~min}$, and $72^{\circ} \mathrm{C}$ for $1 \mathrm{~min}$, with a final extension at $72^{\circ} \mathrm{C}$ for $7 \mathrm{~min}$. Each primer set was amplified using an optimized number of PCR cycles to ensure the linearity requirement for semi-quantitative RT-PCR analysis. The amplified transcripts were visualized on $1.5 \%$ agarose gels with the use of ethidium bromide. Gels were then scanned (Fotodyne Incorporated, WI, USA) and analyzed using Gel-Pro Analyzer 3.1 software (Media Cybernetics, MD, USA).

\subsection{Protein determination}

Protein concentration was evaluated by the method of Bradford (1976), using bovine serum albumin as a standard.

\subsection{Statistics}

Values in the text, figures and tables indicate mean values \pm SEM. Differences among treatments were analyzed by one-way ANOVA, taking $\mathrm{p}<0,05$ as significant according to Tukey's multiple range test. 


\section{Results}

\subsection{Growth parameter}

Experiments were carried out in the presence of different SNP concentrations ranging from 200 to $750 \mu \mathrm{M}$. Root length was measured as a parameter to asses the optimal condition. Figure 1 shows that $250 \mu \mathrm{M}$ SNP brought about a $45 \%$ increase in root length, whereas a diminution was observed under the other concentrations. Depending on its dose, NO can promote or inhibit root growth. According to these result, $250 \mu \mathrm{M}$ SNP was chosen as the concentration to be used in pretreatment.

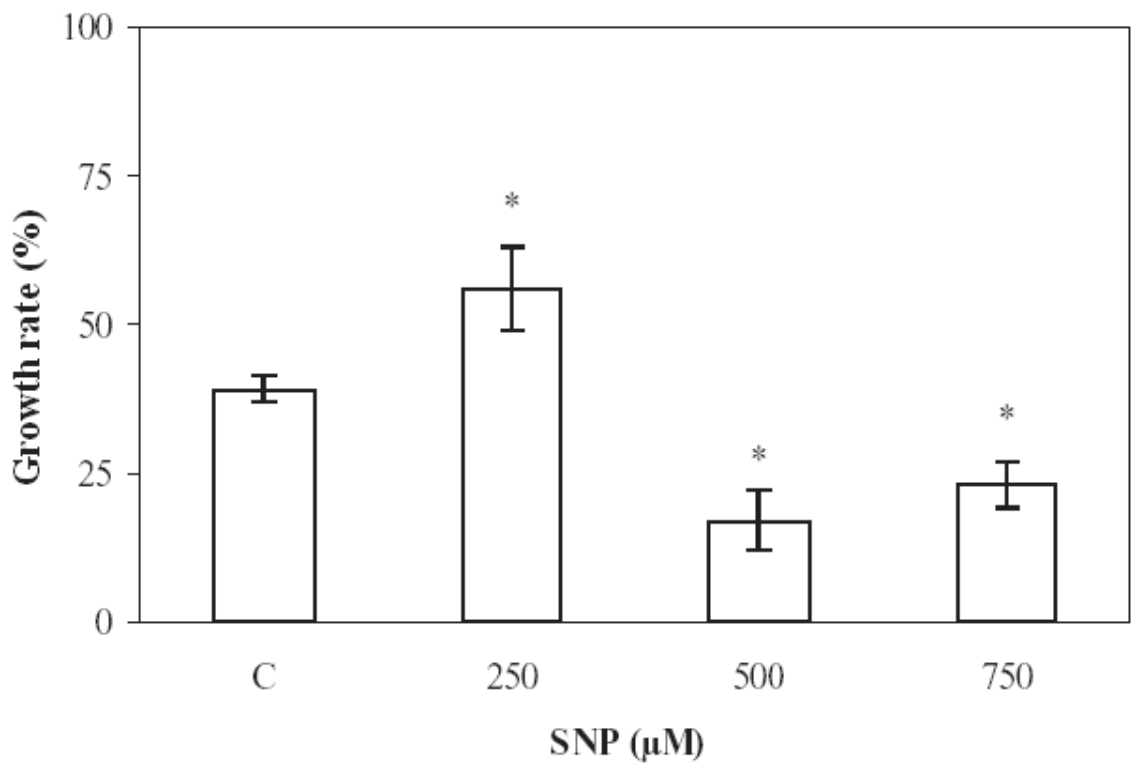

Fig. 1. Effect of different SNP concentrations on root growth. * Significant difference $(\mathrm{p}<$ $0.05)$ according to Tukey's test.

\subsection{Lipid peroxidation}

Increment in TBARS is a good reflection of oxidative damage to membrane lipids and other vital molecules such as proteins, DNA and RNA. Figure 2 shows that TBARS levels increased $75 \%$ respect to controls under salt treatment which is in agreement with results of other studies (Deng et al. 2010).

To complete this analysis, the effect of SNP pre-treatment was evaluated. Figure 2 indicates that in this case, membrane damage was more moderated, as indicated by a $14 \%$ augmentation respect to controls. Treatment with SNP alone did not show any difference respect to controls.

\subsection{Glutathione content}

GSH is a leading substrate for enzymatic antioxidant functions and it is also a known radical scavenger. Previous reports from our laboratory demonstrated that oxidative stress induces the formation of oxidant species and therefore affects GSH content in soybean plants 


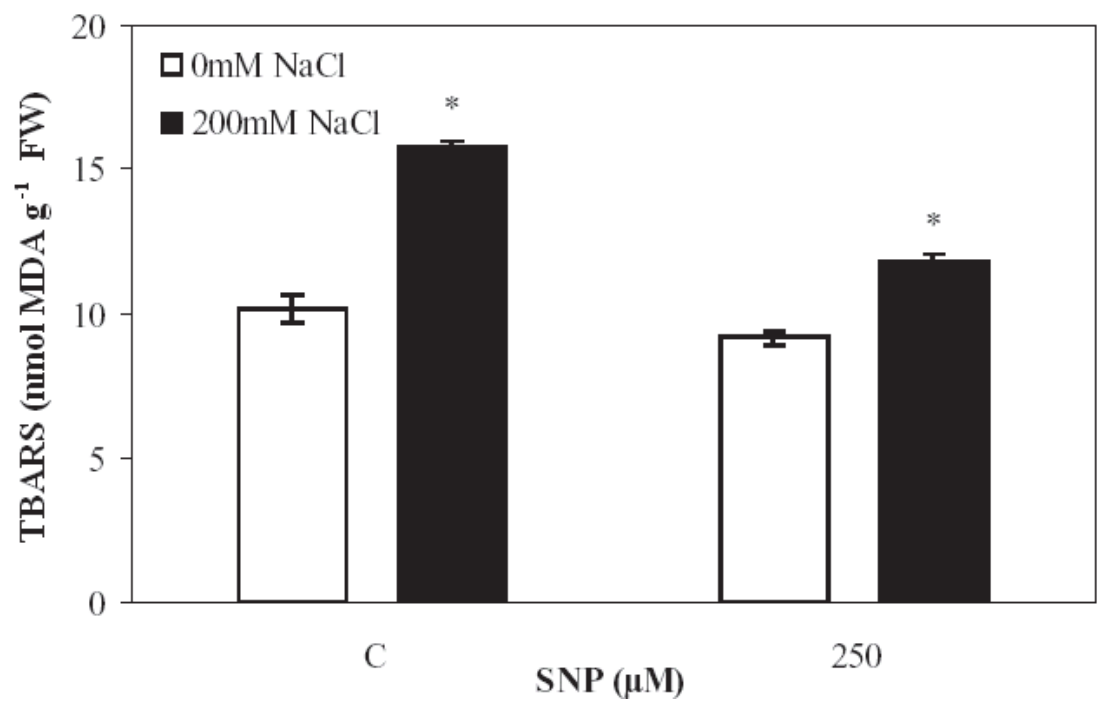

Fig. 2. Effect of salinity on TBARS formation and SNP regulation. * Significant difference $(\mathrm{p}<0.05)$ according to Tukey test.

(Balestrasse et al. 2001 and Noriega et al. 2004). Surprisingly, data in Figure 3 show that GSH concentration in soybean roots treated with $\mathrm{NaCl}$ was enhanced 3.5-fold respect to controls. Pre-treatment with SNP brought about a 4-fold augmentation respect to controls. Moreover, SNP alone provoked a 2-fold increase respect to controls.

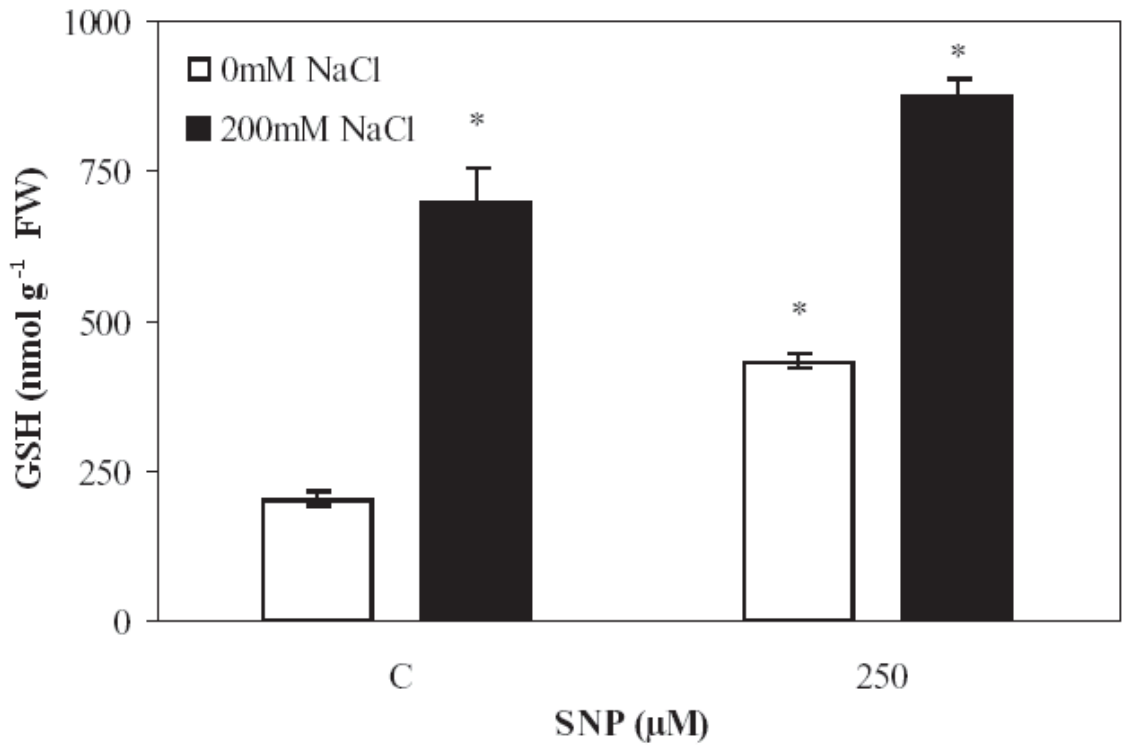

Fig. 3. Effect of salinity on GSH levels and SNP regulation. * Significant difference $(p<0.05)$ according to Tukey test. 


\section{$3.4 \mathrm{H}_{2} \mathrm{O}_{2}$ and $\mathrm{O}_{2}{ }^{--}$localization in situ}

Accumulation of $\mathrm{H}_{2} \mathrm{O}_{2}$ and $\mathrm{O}_{2}$-- were also evaluated in situ by histochemical methods as shown in Figure $4 \mathrm{a} \mathrm{NaCl}$ produced $32 \% \mathrm{H}_{2} \mathrm{O}_{2}$ spots area versus total root area, while pretreatment with $250 \mu \mathrm{M}$ SNP prevented this effect and spot area was similar to controls (Figure 4a). Data in Figure $4 \mathrm{~b}$ showed that roots treated with $\mathrm{NaCl}$ produced $41 \% \mathrm{O}_{2}$ - spots area versus total root area. Pretreatments with $250 \mu \mathrm{M}$ SNP completely prevented the $\mathrm{O}_{2}$ production induced by $\mathrm{NaCl}$.

A

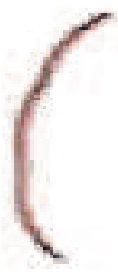

C

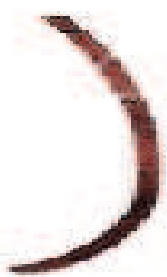

$\mathrm{NaCl}$

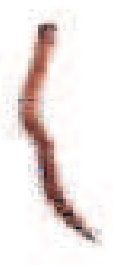

SNP

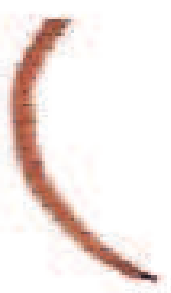

$\mathrm{NaCl}+\mathrm{SNP}$

B
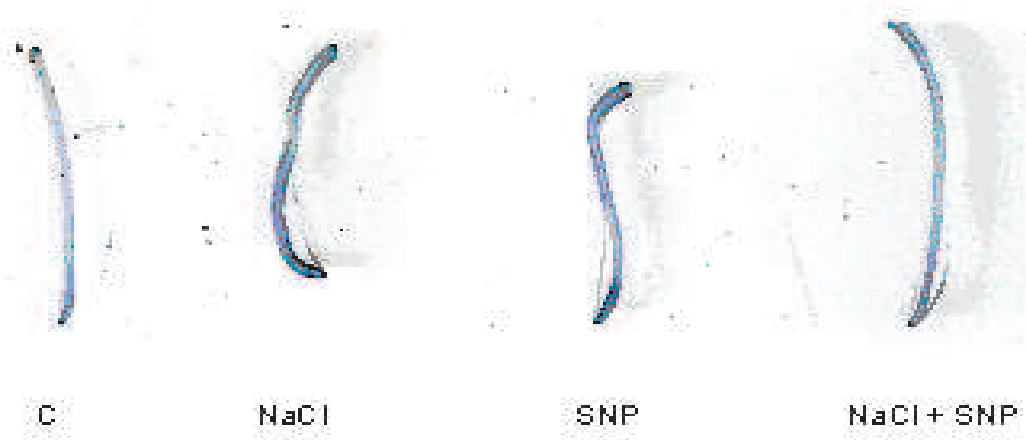

Fig. 4. Histochemical detection of $\mathrm{H}_{2} \mathrm{O}_{2}$ (A) and $\mathrm{O}_{2}-$ (B) in soybean roots. Experiments were performed as described in Materials and Methods. Pictures are representative of three different experiments with three replicated measurements for each treatment.

\subsection{Effect of NO on antioxidant enzyme activities}

We also investigated whether $\mathrm{NO}$ can modulate the activities of classical antioxidant enzymes such as CAT and APX. These are the main $\mathrm{H}_{2} \mathrm{O}_{2}$-scavenging enzymes that control ROS-mediated responses under biotic and abiotic stresses (Mittler 2002). CAT and APX activities were significantly affected by $\mathrm{NaCl}$ (Table 1). They were increased by $47 \%$ and $33 \%$ in NaCl-treated plants compared to controls, respectively. Moreover, CAT activity significantly augmented up to $24 \%$ with respect to controls of SNP-treated plants, whereas APX only showed a mild increase $(19 \%)$. Heme oxygenase behavior was similar to that found for CAT (Table 1). 


\begin{tabular}{|c|c|c|c|}
\hline Treatment & $\begin{array}{c}\text { HO-1 } \\
(\mathrm{U} / \mathrm{mg} \text { protein })\end{array}$ & $\begin{array}{c}\text { CAT } \\
(\mathrm{pmol} / \mathrm{mg} \text { protein })\end{array}$ & $\begin{array}{c}\text { APX } \\
(\mathrm{U} / \mathrm{mg} \text { protein })\end{array}$ \\
\hline Control & $0.065 \pm 0.001^{\mathrm{a}}$ & $120 \pm 12^{\mathrm{a}}$ & $0.0040 \pm 0.0010^{\mathrm{a}}$ \\
\hline $\mathrm{NaCl}$ & $0.073 \pm 0.001^{\mathrm{b}}$ & $176 \pm 9^{\mathrm{b}}$ & $0.0053 \pm 0.0012^{\mathrm{a}}$ \\
\hline $\mathrm{SNP}$ & $0.079 \pm 0.002^{\mathrm{c}}$ & $149 \pm 2^{\mathrm{c}}$ & $0.0047 \pm 0.0010^{\mathrm{a}}$ \\
\hline $\mathrm{SNP}+\mathrm{NaCl}$ & $0.083 \pm 0.004^{\mathrm{c}}$ & $138 \pm 14^{\mathrm{c}}$ & $0.0050 \pm 0.0010^{\mathrm{a}}$ \\
\hline
\end{tabular}

Table 1. Antioxidant enzyme activities in soybean roots subjected to $200 \mathrm{mM} \mathrm{NaCl}$ and 250 $\mu \mathrm{M}$ SNP pretreatment. Enzymatic activities were assayed as described in Materials and Methods. Different letters within columns indicate significant differences $(P<0.05)$ according to Tukey's multiple range test.

\subsection{Heme oxygenase-1 activity and gene expression}

Previous findings from our group demonstrated the protective role that $\mathrm{HO}-1$ plays against oxidative stress in soybean plants (Noriega et al. 2004 and Balestrasse et al. 2005). Figure 5 indicates that salt stress caused HO-1 mRNA induction (13\%, respect to controls). This enhancement is positively correlated with enzyme activity (Table 1). Pretreatment with 250 $\mu \mathrm{M}$ SNP brought about an augmentation of gene expression in control plants $(21 \%)$, as well as salt treated plants (27\%) (Figure 5). Once again, this behavior was also found when enzyme activity was determinated (Table 1).These results indicate on one hand, that NO
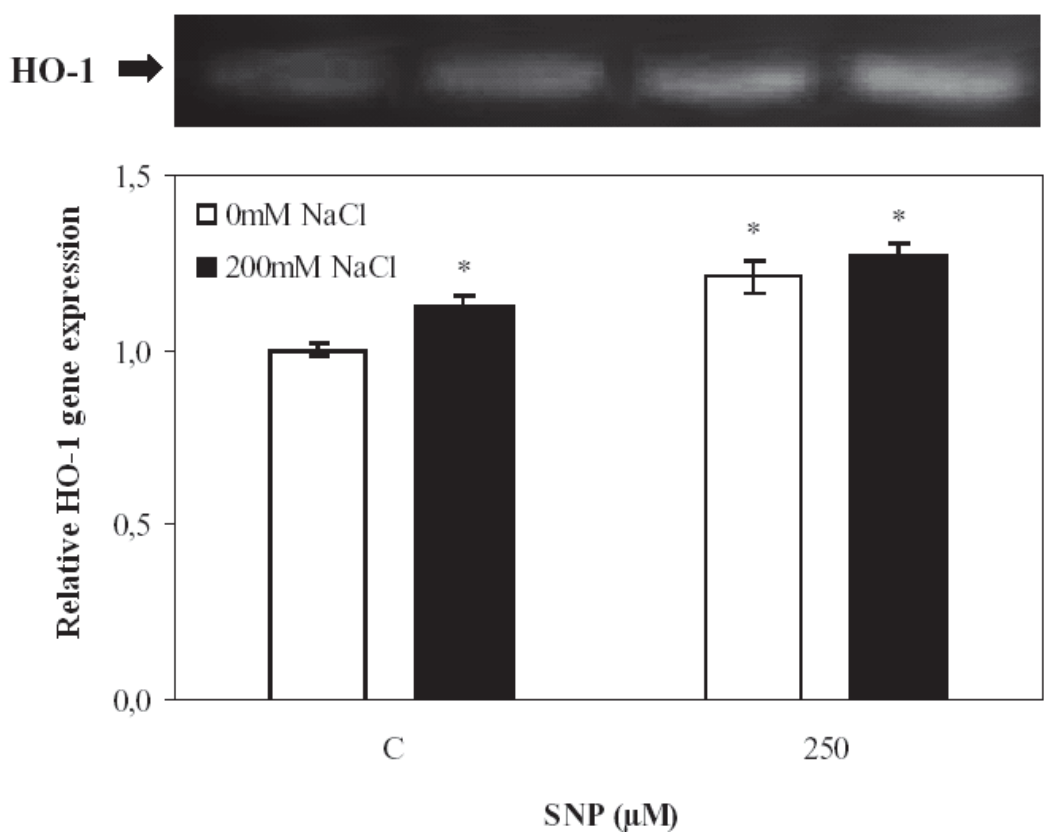

Fig. 5. HO-1 mRNA expression was analyzed by semi-quantitative RT-PCR as described in Materials and Methods. The $18 \mathrm{~S}$ amplification band is shown to confirm equal loading of RNA and RT efficiency. Relative HO-1 transcript expression taking control as $1 \mathrm{U}$. Data are means of three independent experiments and bars indicate SE. *Significant differences $(\mathrm{P}<$ 0.05 according to Tukey test). 
induces $\mathrm{HO}-1$ more efficiently than $\mathrm{NaCl}$, and on the other hand, both compounds have a synergic effect on this induction. To asses whether HO-1 is involved in the protection against $\mathrm{NaCl}$ exerted by $\mathrm{NO}$, experiments were carried out in plants treated with ZnPPIX, a well known irreversible HO-1 inhibitor. Plants with inhibited HO-1 activity can not cope with $\mathrm{NaCl}$ insult (data not shown). We can assume that protection exerted by SNP may be due to the augmentation of the activity of this antioxidant enzyme.

\subsection{Effect of NO and CO}

\subsubsection{Glutathione content}

As already stated, there is a positive relationship between NO content and GSH levels (Figure 3). This result prompted us to investigate whether $\mathrm{HO}$ is involved in the regulation of this tripeptide. To fulfill this purpose, experiments were carried out in plants treated with ZnPPIX and then subjected to NO (HO inductor) or CO (HO reaction product) for $48 \mathrm{~h}$ before salt stress. Afterwards, GSH content (Figure 6) as well as HO-1 gene expression (Figure 8) was determinated.

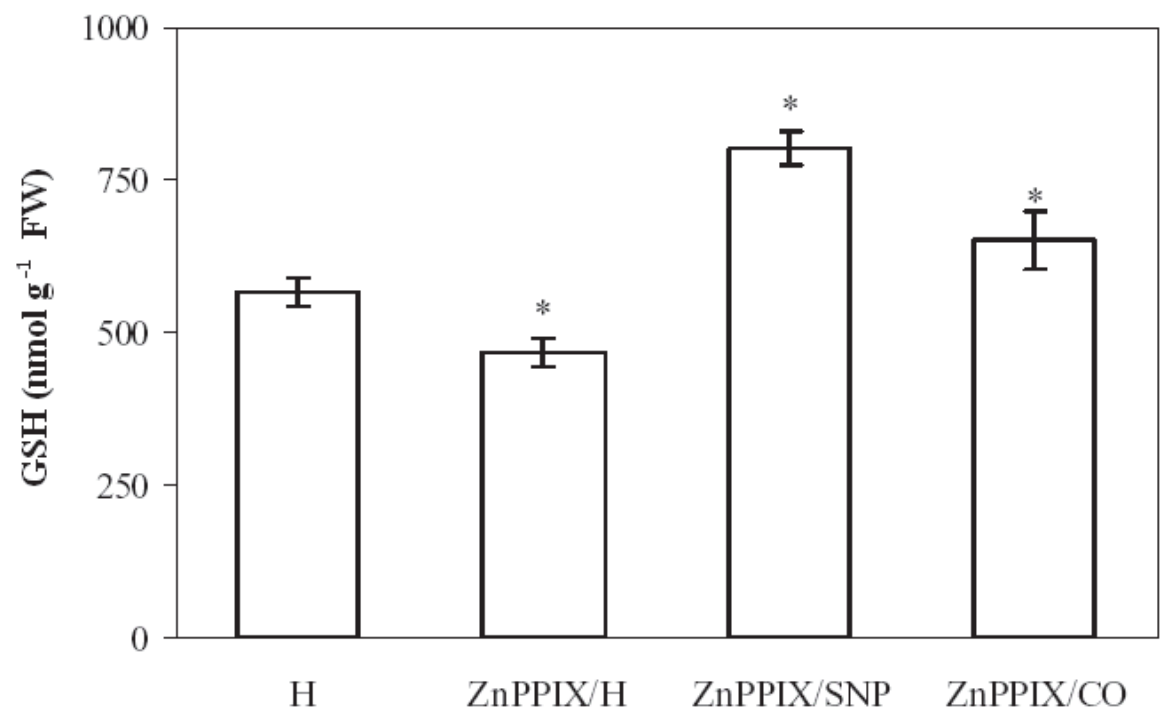

Fig. 6. Effect of $\mathrm{NO}$ and CO on GSH content. (H) Control plants, (ZnPPIX/H) plants pretreated with ZnPPIX and then with $\mathrm{H}$; (ZnPPIX/SNP) plants pretreated with ZnPPIX and then with SNP; (ZnPPIX/CO) plants pretreated with ZnPPIX and then with CO as described in Materias and Methods. * Significant difference $(p<0.05)$ according to Tukey's test.

In plants pretreated with ZnPPIX for $72 \mathrm{~h}$ before Hoagland $(\mathrm{H})$ treatment $(\mathrm{ZnPPIX} / \mathrm{H})$, GSH level diminished $20 \%$ respect to controls $(\mathrm{H})$. Figure 6 shows that NO (ZnPPIX/SNP) as well as CO (ZnPPIX/H) enhanced GSH levels (40\% and 15\%, respectively).

\subsubsection{Glutathione reductase activity}

Taking into account the fact that GSH synthesis is affected by HO-1 inhibition and NO pretreatment GR activity was determinated under the same conditions. Figure 7 indicates a 
positive relationship between GSH levels and GR activity. Enzyme activity (GR) diminished $22 \%$ respect to controls when $\mathrm{HO}$ was inhibited, but an increase was detected in plants treated with $\mathrm{NO}$ and $\mathrm{CO}(33 \%$ and $26 \%$, respectively).

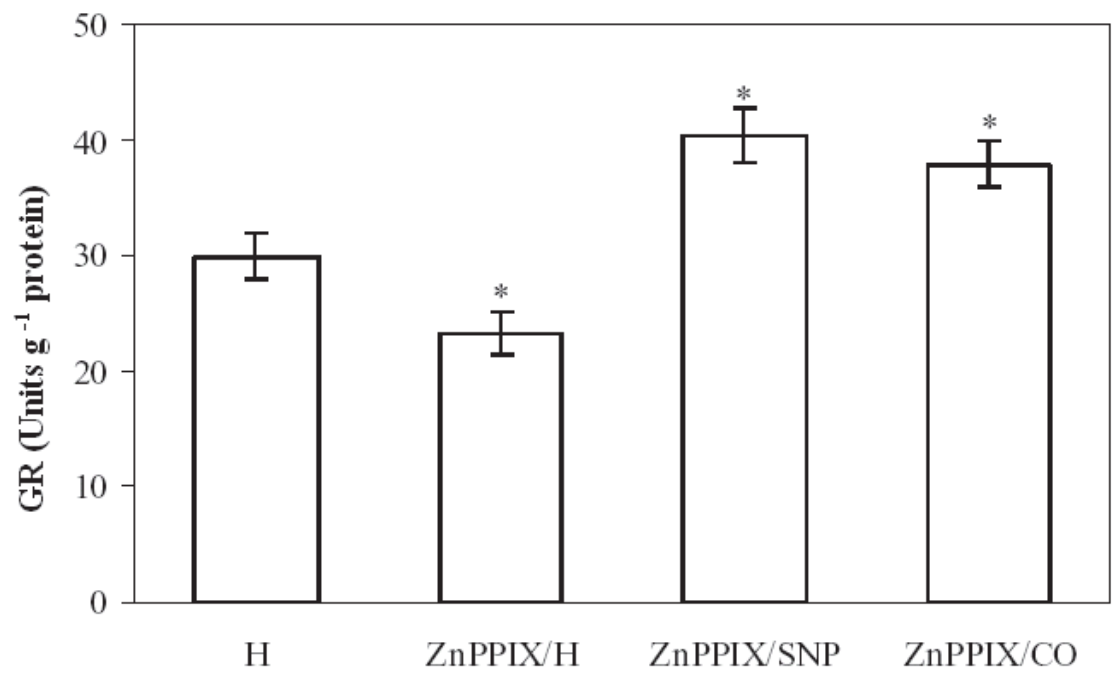

Fig. 7. Effect of $\mathrm{NO}$ or $\mathrm{CO}$ on GR activity. (H) Control plants, (ZnPPIX/H) plants pretreated with ZnPPIX and then with $\mathrm{H}$; (ZnPPIX/SNP) plants pretreated with ZnPPIX and then with SNP; (ZnPPIX/CO) plants pretreated with ZnPPIX and then with CO as described in Materias and Methods. * Significant difference $(\mathrm{p}<0.05)$ according to Tukey's test.

\subsubsection{HO-1 gene expression}

Figure 8 shows HO-1 gene expression under different conditions. ZnPPIX/SNP treatment brought about a $20 \%$ augmentation respect to controls. This increase is positively correlated with GSH content and GR activity. On the other hand, CO did not show any effect. It is interesting to note that the enhancement of GSH content is not related to oxidative stress, since TBARS levels in roots of SNP and CO treated plants do not differ from controls. In contrast, HO inhibition brought about an enhancement (28\%) in TBARS levels.

\section{Discussion}

In a previous work, we found that SNP pre-treatment ameliorates Cd-induced oxidative stress and modulates HO-1 gene expression in soybean plants (Noriega et al. 2007). Taking into account the fact that $\mathrm{NO}$ is involved in various signaling pathways, in the present study we evaluated whether this molecule could enhance $\mathrm{HO}$ activity conferring a major protection against salt stress.

Our data demonstrated that, depending on its concentration, NO can improve the plant antioxidant response against salinity. This model was appropriate to determine the beneficial effect of exogenously added NO. While the lower dose of SNP did not reduce the oxidative damage (data not shown), the application of 500 or $750 \mu \mathrm{M}$ SNP showed a deleterious effect suggesting a pro-oxidant behavior of $\mathrm{NO}$ at these concentrations (Figure 1). 

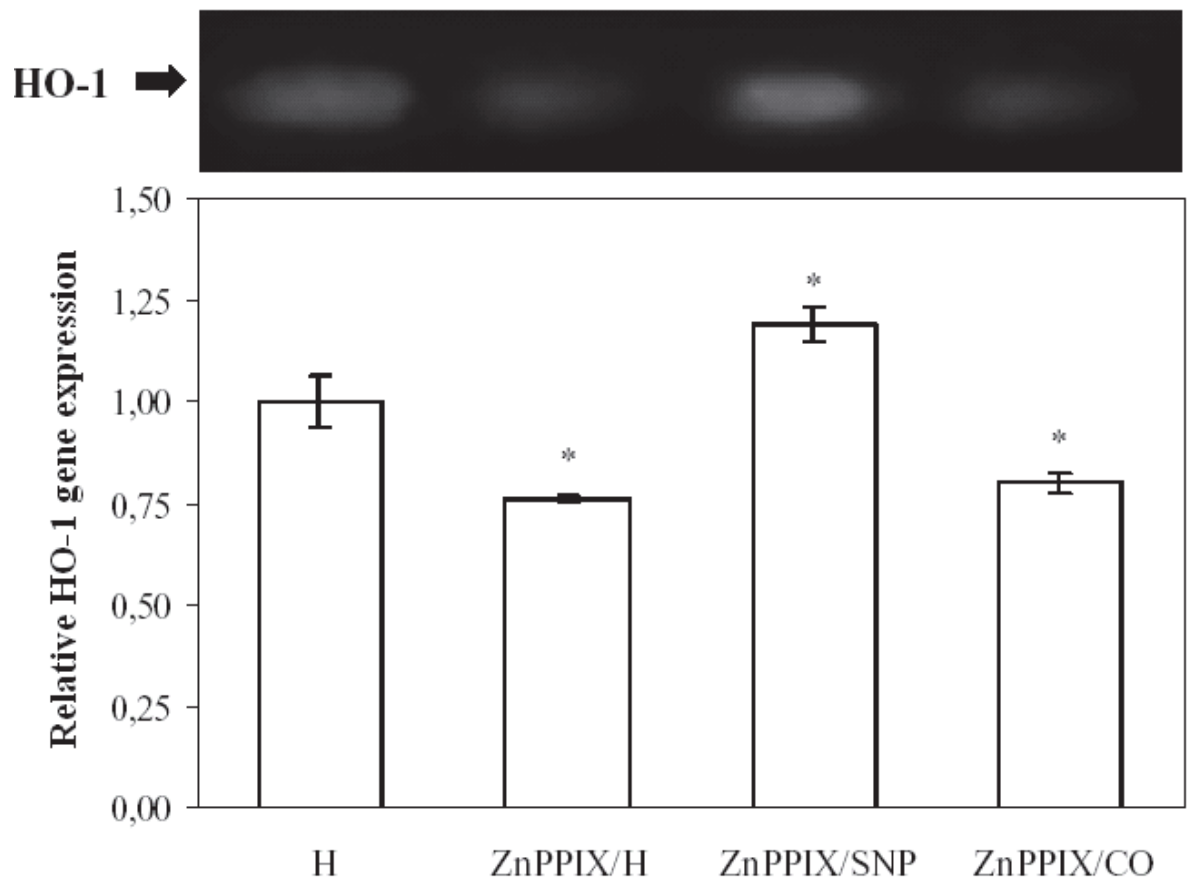

Fig. 8. Effect of NO or CO on HO-1 gene expression. (H) Control plants, (ZnPPIX/H) plants pretreated with ZnPPIX and then with $\mathrm{H}$; (ZnPPIX/SNP) plants pretreated with ZnPPIX and then with SNP; (ZnPPIX/CO) plants pretreated with ZnPPIX and then with CO as described in Materias and Methods. * Significant difference $(p<0.05)$ according to Tukey's test.

The pre-treatments with $250 \mu \mathrm{M}$ SNP effectively ameliorated $\mathrm{NaCl}$-induced oxidative stress, as indicated by the decrease in $\mathrm{H}_{2} \mathrm{O}_{2}$ and $\mathrm{O}_{2}$ - formation (Figure 4), preventing TBARS formation (Figure 2) and enhancing GSH content (Figure 3). The activities of classical antioxidant enzymes, such as CAT and APX were also augmented by SNP treatment, instead of the drastically diminution observed with salinity alone (Table 1). These data are in agreement with reports showing a protective effect of $\mathrm{NO}$ in plants subjected to other stresses (Zhao et al. 2004; Shi et al. 2005 and Noriega et al. 2007). Nevertheless, the molecular mechanism that mediates $\mathrm{NO}$ enhancement of antioxidant enzyme activities is not completely understood. Interestingly, we found that $\mathrm{HO}$ and CAT activities had a similar behaviour with respect to SNP pre-treatment under salinity (Table 1). A recent study showed that the time-course of induction of those enzymes in soybean nodules subjected to Cd stress is related (Balestrasse et al. 2008). These results suggest a close relationship between the signal transduction pathways involved in the response of $\mathrm{HO}$ and CAT after oxidative stress generation and support the antioxidant role of $\mathrm{HO}$. In addition, there was a positive correlation between HO-1 transcript levels and enzyme activity (Figure 5 and Table 1). Previous reports have also demonstrated that the enhancement of $\mathrm{HO}$ activity is associated with an increase in HO-1 transcript levels and protein content (Yannarelli et al. 2006 and Balestrasse et al. 2008). Although this mechanism can account for the changes observed in $\mathrm{HO}$ activity, the incidence of post-translational modifications or different $\mathrm{HO}$ 
isoforms under stress conditions needs to be addressed. Experiments carried out in plants treated with SNP in the absence of $\mathrm{NaCl}$ showed that $\mathrm{NO}$ itself can up-regulate $\mathrm{HO}-1$ mRNA expression, but to a lesser extent (Figure 5). This observation indicates that a certain balance between $\mathrm{NO}$ and ROS is required to trigger the full response. Interestingly, a recent report found that the ROS-NO ratio is important to elicit ROS-activated stress responses and cell death regulation in plant leaves during ozone exposure (Ahlfors et al. 2009). Moreover, new evidence suggests that plastids and peroxisomes are important regulators of NO levels in plants (Corpas et al. 2009 and Gas et al. 2009).

Biliverdin, one of the products of the $\mathrm{HO}$, is an efficient scavenger of ROS and it can account for the antioxidant properties of this enzyme both in animals and plants (Otterbein et al. 2003 and Noriega et al. 2004). More recently, it has been shown that CO released by HO is an important signal molecule for the tolerance mechanisms against cadmium and salt stress (Han et al. 2008). It would be interesting to determine whether CO could also play a role in the defense against salinity in soybean plants.

Pretreatment with ZnPPIX decreased HO-1 expression (Figure 8) and increased parameters of oxidative stress. When the inhibitor was added before NO or $\mathrm{CO}$ treatment, $\mathrm{HO}-1$ expression as well as GSH content (Figure 6) and GR activity were increased (Figure 7). These results let us suppose that a close relationship between HO-1 induction and GSH content could exist. Taking together, these data provide evidence of one of the possible roles that $\mathrm{NO}$, as well as $\mathrm{CO}$ could play against oxidative insult.

\section{Conclusion}

The present study together with previous results (Balestrasse et al. 2008 and Zilli et al. 2008) support the protective role of HO in soybean plants against salinity. Data here reported let us understand the mechanisms involved in $\mathrm{HO}$ response in $\mathrm{NaCl}$-treated soybean plants. This model proposes that NO is implicated in the HO signaling pathway and, together with ROS, modulates the activity of this enzyme under salinity. In plants treated with ZnPPIX, CO did not induce HO-1, but an augmentation of GSH levels as well as GR activity was observed. On the other hand, NO not only caused a more important enhancement in GSH content and GR activity, but also brought about the induction of HO-1. Moreover, NO can enhance the antioxidant system allowing an improved plant defense to the subsequent oxidative insult. Interestingly, while NO may directly potentiate $\mathrm{NaCl}$-induced $\mathrm{HO}-1$ transcription, pre-treatment with SNP followed by salinity stress may protect and enhance by inducing free radical scavenging enzymes and GSH. An appropriate balance of ROS-NO is necessary to trigger the full $\mathrm{HO}$ response. In contrast to other stress conditions, induction of HO-1 occurs together with an enhancement of GSH levels and GR activity. In conclusion, the present study provides new insights into the molecular response of soybean plants to salinity and also evidences that $\mathrm{HO}$ plays an important role during stress conditions.

\section{Acknowledgments}

We thank Dr T. Kohchi for kindly providing the Arabidopsis HO-1 antibodies. This work was supported by grants from the Universidad de Buenos Aires (Argentina) and from Consejo Nacional de Investigaciones Científicas y Técnicas (CONICET) (Argentina). M.L.T and K.B.B. are career investigators from CONICET. 


\section{References}

Ahlfors, R.; Broschél, M.; Kollist, H.; Kangasjärvil, J. (2009). Nitric oxide modulates ozoneinduced cell death, hormone biosynthesis and gene expression in Arabidopsis thaliana. Plant Journal, Vol.58, No.1, pp.1-12, ISSN 0960-7412.

Anderson, E. (1985). Determination of glutathione and glutathione disulfide in biological samples, Methods in Enzymology. Vol.113, pp. 548-554, ISSN 0076-6879

Balestrasse, K.; Gardey, L.; Gallego, S. \& Tomaro, M. (2001). Response of antioxidative defense system in soybean nodules and roots subjected to cadmium stress. Australian Journal of Plant Physiology, Vol.28, pp.497-504. ISSN 0310-784.

Balestrasse, K.; Noriega, G.; Batlle; A. \& Tomaro, M. (2005). Involvement of Heme Oxygenase as Antioxidant Defense in Soybean Nodules, Free Radical Research, Vol.39, No.2, pp.145-51. ISSN 1071-5762.

Balestrasse, K.; Zilli, C. \& Tomaro, M. (2008). Signal transduction pathways and haem oxygenase induction in soybean leaves subjected to salt stress, Redox Report,Vol.13; No. 6, (December 2008), pp. 255-262, ISSN 1351-0002.

Balestrasse, K.;Gardey, L.; Gallego, S. \& Tomaro, M. (2001). Response of antioxidant defence system in soybean nodules and roots subjected to cadmium stress, Australian Journal of Plant Physiology. Vol.28, pp.497-504, ISSN 0310-7841.

Beligni, M. \& Lamattina, L. (1999). Is nitric oxide toxic or protective?. Trends in Plant Science, Vol.4, No.8, (August 1999), pp. 299-300, ISSN.

Beligni, M. \& Lamattina,L. (2001). Nitric oxide: a non-traditional regulator of plant growth, Trends in Plant Science, Vol6, No. 11, (November 2001), pp. 508-509, ISSN 1360-1385.

Boveris, A. \& Poderoso, J. (2000). Regulation of Oxygen Metabolism by Nitric Oxide, Nitric Oxide, Vol.51, pp. 355-368, ISSN 1089-8306.

Bradford, M. (1976). A rapid and sensitive method for the quantitation of microgram quantities of protein utilizing the principle of protein-dye binding, Analytical Biochemistry, Vol.72, pp.248-254, ISSN 0003-2697.

Colburn, NH.(1992). Gene regulation by active oxygen and other stress inducers, Spatz L, Bloom AD (eds) Biological consequences of oxidative stress, pp 121-137, ISBN 10: 0195072960, Oxford University Press, New York.

Corpas, F.; Palma, J.; Del Río, L. \& Barroso, J. (2009). Evidence supporting the existence of 1arginine-dependent nitric oxide synthase activity in plants, New Phytologist, Vol.184, pp.1-3, ISSN 0028-646X.

Darwish, E.; Testerink, C.; Khalil, M.; El-Shihy, O. \& Munnik, T. (2009). Phospholipid Signaling responses in salt-Stressed Rice Leaves. Plant and Cell Physiology, Vol.50, No.5, pp.986-99, ISSN 0032-0781.

Demiral, T. \& Turkan, I. (2005). Comparative lipid peroxidation, antioxidant defense systems and proline content in roots of two rice cultivars differing in salt tolerance, Environmental and Experimental Botany, Vol.53, pp. 247-257, ISSN 0098-8472.

Garcia-Mata, C. \& Lamattina, L. (2007). Abscisic acid (ABA) inhibits light-induced stomatal opening through calcium- and nitric oxide-mediated signaling pathways Nitric Oxide, Vol.17, No.3-4, (November-December 2007), pp.143-151, ISSN 1089-8306.

Harminder, P.; Shalinder Kaur, S.; Batish, D.; Sharma, V.; Sharma, N. \& Kohli, R. (2009). Nitric oxide alleviates arsenic toxicity by reducing oxidative damage in the roots of Oryza sativa (rice), Nitric Oxide, Vol.20, No.4, (June 2009), pp. 289-297, ISSN 10898306. 
Hay, R. \& Porter, J. (2006). The physiology of crop yield, Wiley-Blackwell Publishing, ISBN 1405108592, Singapore.

Heath, R. \& Packer, L. (1968). Photoperoxidation in isolated chloroplasts. I Kineties and stoichiometry of fatty acid peroxidation, Archives of Biochemistry and Biophysics, Vol.125, pp.189-198, ISSN 0003-9861.

Jasid, S.; Galatro, A.; Villordo, J.; Puntarulo, S. \& Simontacchi, M. (2009).Role of nitric oxide in soybean cotyledon senescence, Plant Science, Vol. 176, No. 5, (May 2009), pp.662668, ISSN 0168-9452.

Kikuchi, G.;Yoshida, T. \& Noguchi, M. (2005). Heme oxygenase and heme degradation, Biochemistry and Biophysical Research Communication, Vol. 338, pp.558-567, ISSN 0006-291X.

Leitner , M.; Vandelle, E.; Gaupels, F.;Bellin,D.\& Delledonne, F. (2009). NO signals in the haze Nitric oxide signalling in plant defence, Current Opinion in Plant Biology, Vol.12, pp.451-458. ISSN 1369-5266.

Liu, Y.; Xu, S.; Ling, T.; Xu, L. \& Shen, W. (2010). Heme oxygenase/carbon monoxide system participates in regulating wheat seed germination under osmotic stress involving the nitric oxide pathway, Journal of Plant Physiology, Vol.167, pp. 1371-1379, ISSN 0176-1617.

Mackernessa, S.; Johna, F.; Jordan, B. \& Thomasa, B. (2001). Early signaling components in ultraviolet-B responses: distinct roles for different reactive oxygen species and nitric oxide, FEBS Letters, Vol.489, pp.237-242, ISSN 0014-5793.

Mandhania, S.; Madan, S. \& Sawhney, V. (2006). Antioxidant defense mechanism under salt stress in wheat seedlings, Biologia Plantarum, Vol.227, pp. 227- 231, ISSN 0006-3134.

Martin, M.; Rodríguez Colman,M.; Gómez-Casati, D.; Lamattina, L. \& Julián, E. Zabaleta. (2009). Nitric oxide accumulation is required to protect against iron-mediated oxidative stress in frataxin-deficient Arabidopsis plants, FEBS Letters, Vol.583, No.3, (February 2009), pp. 542-548, ISSN 0014-5793.

Mittler, R. (2002) Oxidative stress, antioxidants and stress tolerance, TRENDS in Plant Science, Vol.7, No.9, (September 2002),pp.521-546, ISSN 1360-1385.

Muramoto, T.; Tsurui, N.; Terry, M.; Yokota, A. \& Kohchi, T. (2002). Expression and biochemical properties of a ferredoxin-dependent heme oxygenase required for phytochrome chromophore synthesis. Plant Physiology, Vol.130, pp.1958-1966, ISSN 0032-0889.

Nakano, Y. \& Asada, K. (1981). Hydrogen peroxide is scavenged by ascorbate-specific peroxidase in spinach chloroplast. Plant and Cell Physiology, Vol.22, pp.867-880, ISSN 0032-0781.

Noriega, G.; Balestrasse, K.; Batlle, A \& Tomaro, M. (2004). Heme oxygenase exerts a protective role against oxidative stress in soybean leaves. Biochemical and Biophysical Research Communications. Vol.323, pp. 1003-1008, ISSN 0006-291X.

Noriega, G.; Yannarelli, G.; Balestrasse, K.; Batlle, A. \& Tomaro, M. (2007). The effect of nitric oxide on heme oxygenase gene expression in soybean leaves, Planta, Vol. 226, pp.1155-1163, ISSN 0032-0935.

Nürnberger, T. \& Scheel, D. (2001) Signal transmission in the plant immune response, TRENDS in Plant Science, Vol.6, No.8 (August 2001), pp. 551-579, ISSN 1360-1385. 
Otterbein, L.; Soares, M.; Yamashita, K. \& Bach, F. (2003). Hemeoxygenase-1:unleashing the protective properties of heme. Trends Immunology, Vol.24, pp.449-455, ISSN 14714906.

Parani, M. ; Rudrabhatla. S.; Myers, R.; Weirich, H.; Smith, B.; Leaman, B. \& Goldman, S. (2004). Microarray analysis of nitric oxide responsive transcripts in Arabidopsis, Plant Biotechnology Journal, Vol.2, pp.359-366, ISSN 14677644.

Romero-Puertas, M.; Rodríguez-Serrano, M.; Corpas, F.; Gómez, M.; Del Río, L. \& Sandalio, L. (2004). Cadmium-induced subcellular accumulation of $\mathrm{O}_{2}-$ and $\mathrm{H}_{2} \mathrm{O}_{2}$ in pea leaves, Plant and Cell Environment, Vol.27, pp.1122-1134, ISSN 0140-7791.

Santa-Cruz, D.;Pacienza, N.; Polizio A., Balestrasse K.;Tomaro M. \& Yannarelli, G. (2010). Nitric oxide synthase-like dependent NO production enhances heme oxygenase up-regulation in ultraviolet-B-irradiated soybean plants. Phytochemistry, Vol.71, pp.1700-1707, ISSN.

Shaedle, M. \& Bassham, J. (1977). Chloroplast glutathione reductase, Plant Physiology, Vol. 59, pp.1011-1012, ISSN 0031-9422.

Shantel, A.; Fowler, R.; Virgen, A.; Gossett, D.; Banks, S. \& Rodriguez, S. (2008). Opposing roles for superoxide and nitric oxide in the $\mathrm{NaCl}$ stress-induced upregulation of antioxidant enzyme activity in cotton callus tissue, Environmental and Experimental Botany, Vol.62, No.1, (January 2008), pp. 60-68, ISSN 0098-8472.

Shi, S.; Wang, G.; Wang, Y.; Zhang, L. \& Zhang, L. (2005). Protective effect of nitric oxide against oxidative stress under ultraviolet-B radiation, Nitric Oxide, Vol.13, pp.1-9, ISSN 1089-8603.

Sies, H. (1993). Damage to plasmid DNA by singlet oxygen and its protection. Mutation Research/Genetic Toxicology, Vol. 299, No.3-4, May 1993, pp 183-191, ISSN 1383-5718.

Terry, M.; Linley, P. \& Kochi, T. (2002). Making light of it: the role of plants heme oxygenases in phytochrome chromophore synthesis, Biochemical Society Transactions, Vol. 30, pp. 604-609, ISSN 0300-5127.

Terry, M.; Linley, P. \& Kochi, T. (2002). Making light of it: the role of plants heme oxygenases in phytochrome chromophore synthesis, Biochemical Society Transactions, Vol. 30, pp.604-609, ISSN 0300-5127.

Tomaro, M., Batlle, A. (2002). Bilirubin: its role in cytoprotection against oxidative stress. International Journal of Biochemistry and Cell Biology, Vol.34, pp.216-220. ISSN 13572725 .

Wilson, I.; Neill, S. \& Hancock, J. (2008).Nitric oxide synthesis and signalling in plants, Plant Cell and Environment, Vol.31, pp.622-631, ISSN 0140-7791.

Xuan, Y.; Zhou, S.; Wang, L.; Cheng, Y. \& Zhao L. (2010). Nitric Oxide Functions as a Signal and Acts Upstream of AtCaM3 in Thermotolerance in Arabidopsis Seedling, Plant Physiology. Vol.153, pp.1443-1444, ISSN 0032-0889.

Yaacov,Y.; Leshem, R.;Wills, B. \& Veng-Va Ku, W. (1998). Evidence for the function of the free radical gas - nitric oxide $(\mathrm{NO} \bullet)-$ as an endogenous maturation and senescence regulating factor in higher plants, Plant Physiology and Biochemistry, Vol. 36, No. 11, (November 1998), pp. 825-833, ISSN 0981-9428.

Yannarelli, G.; Noriega, G.; Batlle, A. \& Tomaro, M. (2006). Heme oxygenase up-regulation in ultraviolet-B irradiated soybean plants involves reactive oxygen species, Planta, Vol.224, pp.1164-1172, ISSN 0032-0935. 
Zhao, L.; Zhang, F.; Guo, J.; Yang, Y.; Li, B. \& Zhang, L. (2004). Nitric oxide functions as a signal in salt resistance in the calluses from two ecotypes of reed (Phragmites communis Trin.). Plant Physiology, Vol.134, pp.849-857. ISSN 0032-0889.

Zilli, C.; Santa-Cruz, D.; Yannarelli, G.; Noriega, G.; Tomaro, M. \& Balestrasse, K. (2009). Heme Oxygenase Contributes to Alleviate Salinity Damage in Glycine max L. Leaves, International Journal of Cell Biology. Published online (September 2009), PMCID: PMC2809017. 


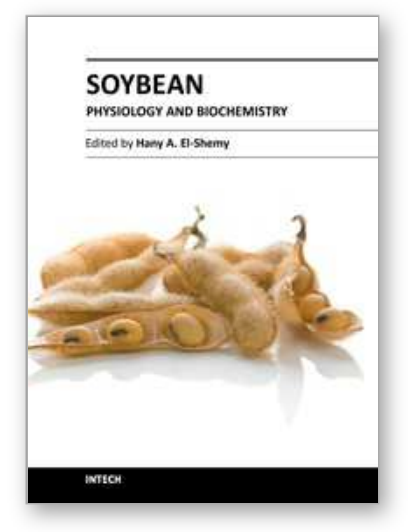

\author{
Soybean Physiology and Biochemistry \\ Edited by Prof. Hany El-Shemy
}

ISBN 978-953-307-534-1

Hard cover, 488 pages

Publisher InTech

Published online 02, November, 2011

Published in print edition November, 2011

Worldwide, soybean seed proteins represent a major source of amino acids for human and animal nutrition. Soybean seeds are an important and economical source of protein in the diet of many developed and developing countries. Soy is a complete protein and soyfoods are rich in vitamins and minerals. Soybean protein provides all the essential amino acids in the amounts needed for human health. Recent research suggests that soy may also lower risk of prostate, colon and breast cancers as well as osteoporosis and other bone health problems and alleviate hot flashes associated with menopause. This volume is expected to be useful for student, researchers and public who are interested in soybean.

\title{
How to reference
}

In order to correctly reference this scholarly work, feel free to copy and paste the following:

Guillermo Noriega, Carla Zilli, Diego Santa Cruz, Ethel Caggiano, Manuel López Lecube, María Tomaro and Karina Balestrasse (2011). Up-Regulation of Heme Oxygenase by Nitric Oxide and Effect of Carbon Monoxide on Soybean Plants Subjected to Salinity, Soybean Physiology and Biochemistry, Prof. Hany El-Shemy (Ed.), ISBN: 978-953-307-534-1, InTech, Available from: http://www.intechopen.com/books/soybean-physiology-andbiochemistry/up-regulation-of-heme-oxygenase-by-nitric-oxide-and-effect-of-carbon-monoxide-on-soybeanplants-subj

\section{INTECH}

open science | open minds

\author{
InTech Europe \\ University Campus STeP Ri \\ Slavka Krautzeka 83/A \\ 51000 Rijeka, Croatia \\ Phone: +385 (51) 770447 \\ Fax: +385 (51) 686166 \\ www.intechopen.com
}

\author{
InTech China \\ Unit 405, Office Block, Hotel Equatorial Shanghai \\ No.65, Yan An Road (West), Shanghai, 200040, China \\ 中国上海市延安西路65号上海国际贵都大饭店办公楼 405 单元 \\ Phone: +86-21-62489820 \\ Fax: +86-21-62489821
}


(C) 2011 The Author(s). Licensee IntechOpen. This is an open access article distributed under the terms of the Creative Commons Attribution 3.0 License, which permits unrestricted use, distribution, and reproduction in any medium, provided the original work is properly cited. 